\title{
PENGARUH JENIS PELARUT DAN ULTRASONIKASI TERHADAP EKSTRAK FIKOERITRIN DARI Kappaphycus alvarezii
}

\author{
Anne Mumtaza Putri*, Uju, Safrina Dyah Hardiningtyas \\ Diterima: 30 Mei 2021/Disetujui: 31 Agustus 2021 \\ Korespondensi: annemumtaza@gmail.com
}

Departemen Teknologi Hasil Perairan, Fakultas Perikanan dan Ilmu Kelautan, IPB University

Cara sitasi: Putri AM, Uju, Hardiningtyas SD. 2021. Pengaruh jenis pelarut dan ultrasonikasi terhadap ekstrak fikoeritrin dari Kappaphycus alvarezii. Jurnal Pengolahan Hasil Perikanan Indonesia. 24(2): 269-283.

\begin{abstract}
Abstrak
Kappaphycus alvarezii merupakan salah satu jenis rumput laut merah (Rhodophyta) yang mengandung pigmen fikobiliprotein. Rumput laut merah didominasi oleh fikobiliprotein berjenis fikoeritrin. Tujuan dari penelitian ini adalah menentukan pengaruh jenis pelarut dan waktu akselerasi ekstraksi ultrasonikasi terhadap pigmen fikoeritrin. Proses ekstraksi dilakukan secara bertahap menggunakan pelarut akuades, $\mathrm{CaCl}_{2}$ dan bufer fosfat dengan akselerasi ultrasonikasi 35-55 menit. Hasil penelitian menunjukkan bahwa ekstrak pigmen fikoeritrin $K$. alvarezii menggunakan akuades menghasilkan warna pigmen lebih pekat dengan konsentrasi tertinggi $0,057 \mathrm{mg} / \mathrm{mL}$ dan indeks kemurnian 0,189 . Konsentrasi pigmen fikoeritrin sebelum dan sesudah presipitasi berturut-turut $0,170 \mathrm{mg} / \mathrm{mL}$ dan $0,421 \mathrm{mg} / \mathrm{mL}$. Indeks kemurnian pigmen fikoeritrin sebelum dan sesudah presipitasi berturut-turut 0,301 dan 0,831. Aktivitas antioksidan (\% inhibisi) terbaik ada pada konsentrasi pigmen fikoeritrin 50 ppm dan 80 ppm dengan lama waktu ekstraksi 45 menit berturut-turut $62 \%$ dan $89 \%$. Profil protein dengan SDS-Page menunjukkan fikoeritrin memiliki bobot molekul $16 \mathrm{kDa}$ pada subunit $\alpha, 17 \mathrm{kDa}$ pada subunit $\beta$, dan $30 \mathrm{kDa}$ pada subunit $\gamma$.
\end{abstract}

Kata kunci: akuades, fikobiliprotein, pigmen, rumput laut

\section{The Effect of Different Solvent Type on Phycoerithryn Extract from Kappaphycus alvarezii}

\begin{abstract}
Kappaphycus alvarezii is a type of red seaweed (Rhodophyta) which contains phycobiliprotein pigments. Red seaweed is dominated by phycoerythrin type phycobiliprotein. The purpose of this study was to determine the effect of solvent type and acceleration time of ultrasonication extraction on phycoerythrin pigments. The extraction process was carried out in stages using aquadest, $\mathrm{CaCl}_{2}$ and buffer phosphate with ultrasonication acceleration of 35-55 minutes. The results showed that the phycoerythrin pigment extract of $K$. alvarezii using distilled water produced a more concentrated pigment color, showing the highest concentration of $0.057 \mathrm{mg} / \mathrm{mL}$, and a purity index of 0.189 . The concentration of phycoerythrin pigment before and after precipitation was $0.170 \mathrm{mg} / \mathrm{mL}$ and $0.421 \mathrm{mg} / \mathrm{mL}$, respectively. The phycoerythrin pigment purity index before and after precipitation was 0.301 and 0.831 , respectively. The best antioxidant activity (\% inhibition) was found at concentrations of $50 \mathrm{ppm}$ and $80 \mathrm{ppm}$ phycoerythrin pigment with extraction time of 45 minutes at $62 \%$ and $89 \%$ respectively. Protein profile using SDS-Page showed that phycoerythrin has a molecular weight of $16 \mathrm{kDa}$ in the subunit $\alpha, 17 \mathrm{kDa}$ in the subunit $\beta$, and $30 \mathrm{kDa}$ in the subunit $\gamma$.
\end{abstract}

Keywords: aquadest, phycobiliprotein, pigment, seaweed 


\section{PENDAHULUAN}

Rumput laut dibagi menjadi tiga kelas yaitu Chlorophyta (rumput laut hijau), Phaeophyta (rumput laut cokelat) dan Rhodophyta (rumput laut merah). Masingmasing memiliki karakteristik pigmen yang khas (Murtoyo et al. 2010). Kappaphycus alvarezii merupakan spesies rumput laut merah (Rhodophyta) yang sering dimanfaatkan dan banyak dikembangkan di Indonesia (Fretes et al. 2012).

Rumput laut merah mengandung pigmen klorofil, karotenoid dan fikobiliprotein (D’Alessandro dan Antoniosi 2016). Fikobiliprotein merupakan pigmen larut air yang terdiri dari allofikosianin, fikosianin, dan fikoeritrin (Sethilkumar et al. 2013). Struktur subunit fikoeritrin berupa ( $\alpha \beta) 6 \gamma$ dengan berat molekul $240 \mathrm{kDa}$ (protein oligomer) (Rossano et al. 2003) serta memiliki dua tipe kromofor yaitu $\mathrm{f}$ (fluorescing) serta $\mathrm{s}$ (sensitizing) dengan nilai absorbansi maksimal sekitar $580 \mathrm{~nm}$ (Tandeau 2003).

Fikobiliprotein sudah dimanfaatkan secara luas di bidang kesehatan, sebagai fotosensitiser pada terapi penyakit kanker (Niu et al. 2006). Fikoeritrin merupakan pewarna alami alternatif yang lebih aman dari pewarna sintesis yang bersifat karsinogen. Pigmen fikobiliprotein dapat dimanfaatkan dalam bidang farmasi dan biomedis (El-aty et al. 2014).

Fikoeritrin dapat diperoleh dari proses ekstraksi. Ekstraksi yang saat ini banyak dilakukan yaitu menggunakan metode freeze and thaw. Kelemahan dari metode tersebut yaitu membutuhkan waktu yang lama dengan hasil ekstrak rendah (Hemwimol et al. 2006). Menurut Mayasari et al. (2018), metode freeze and thaw memiliki kelemahan antara lain membutuhkan energi yang besar dan biaya mahal, sehingga dibutuhkan metode alternatif untuk ekstraksi fikoeritrin.

Ultrasonik adalah cara ekstraksi non termal yang efektif serta efisien. Efek mekanik dari gelombang ultrasonik membuat penetrasi cairan ke dinding membran sel meningkat, mendorong dilepaskannya komponen sel serta membuat transfer massa meningkat (Handaratri dan Yuniati 2019). Hal tersebut disebabkan gelombang ultrasonik menghasilkan gelombang kavitasi yang diduga mampu meningkatkan efektivitas perpindahan massa ke titik pusat dalam waktu singkat (Balachandran et al. 2006). Ultrasonik memiliki kisaran frekuensi antara $20 \mathrm{kHz}-1 \mathrm{MHz}$ (Kentish dan Ashokkumar 2011). Dibandingkan dengan teknik ekstraksi gelombang mikro, ekstraksi perangkat ultrasonik lebih murah dan jauh lebih mudah (Liu et al. 2010).

Penggunaan ultrasonik sebagai alat bantu ekstraksi pigmen telah banyak dilaporkan misalnya pigmen kuning Physalis pubescens L (Wang et al. 2018), pada pigmen Dioscorea cirrhosa (Zhong et al. 2019), dan pada pigmen kuning dari bunga Tecoma castanifolia (Sharmila et al. 2019). Uju et al. (2020) melaporkan bahwa ekstraksi fikoeritrin dengan akselerasi ultrasonikasi dapat mempercepat proses ekstraksi empat kali dari ekstraksi konvensional. Namun, lama waktu ultrasonikasi dan penggunaan jenis pelarut perlu diteliti lebih lanjut untuk meningkatkan kualitas dan kuantitas pigmen yang dihasilkan. Berdasarkan sifat polaritas dari pigmen fikoeritrin yang dapat larut dalam pelarut polar (Graham dan Wilcox 2000), bufer fosfat, akuades, dan $\mathrm{CaCl}_{2}$ dapat digunakan sebagai pelarut pada proses ekstraksi pigmen fikoeritrin. Penelitian ini bertujuan menentukan pengaruh tipe pelarut serta waktu akselerasi ekstraksi ultrasonikasi pigmen fikoeritrin.

\section{BAHAN DAN METODE Bahan dan Alat}

Bahan-bahan yang digunakan pada penelitian ini yaitu rumput laut $K$. alvarezii diperoleh dari Desa Lontar, Kabupaten Serang, Banten, bufer fosfat $\left(\mathrm{NaH}_{2} \mathrm{PO}_{4}\right.$ dan $\left.\mathrm{Na}_{2} \mathrm{HPO}_{4}\right)$ $0,1 \mathrm{M} \mathrm{pH} 7, \mathrm{CaCl}_{2} 1 \%$. Amonium sulfat $60 \%$ (Merck), 1,1-difenil-1-pikrilhidrazil (DPPH) Sigma, unstained marker BioRad (10-250 kDa) $250 \mu \mathrm{L} \times 2$, air untuk injeksi bebas pirogen (IKAPHARMINDO), etanol 30\%, asam asetat $1 \%$, asam asetat $10 \%, \mathrm{AgNO}_{3} 0,1 \%, \mathrm{NaCO}_{3}$ $2,5 \%$, formaldehida $0,02 \%$, akrilamida $30 \%$ (Sigma), sodium dodecyl sulfate (SDS) $10 \%$, amonium persulfat (APS) 10\%, 1,4 M Tris$\mathrm{Cl} \mathrm{pH}$ 6,8, 1,4 M Tris-Cl pH 8,8, gliserol, merkaptoetanol, bromofenol biru. 
Alat-alat yang digunakan pada penelitian ini yaitu blender Panasonic (MX-101SG1), spektrofotometer uv-vis (Perkin Elmer PartNo. B0631009), kantong membran dialisis $14 \mathrm{kDa}$ (Ward's Science), kertas saring Whatman No. 42, pembersih ultrasonik 40 $\mathrm{kHz}$ dengan daya $200 \mathrm{~W}$ (DSA100-SK4.0L, China), pengaduk magnet (Scilogex MSH280Pro, AS), sentrifus (Shimadzu CR21G Himac, Jepang).

\section{Metode Penelitian}

Penelitian ini menggunakan tiga variabel bebas yaitu jenis pelarut (akuades $\mathrm{pH} 7$, bufer fosfat $\left(\mathrm{NaH}_{2} \mathrm{PO}_{4}\right.$ dan $\left.\mathrm{Na}_{2} \mathrm{HPO}_{4}\right) 0,1 \mathrm{M} \mathrm{pH}$ 7, $\mathrm{CaCl}_{2}$ 1\%). Rasio pelarut 1:10 dan lama ekstraksi 30 menit.

\section{Ekstraksi pigmen fikoeritrin (Sudhakar et al. 2014 dengan modifikasi)}

Pigmen fikoeritrin dari rumput laut $K$. alvarezii diekstrak dengan pelarut bufer fosfat $0,1 \mathrm{M} \mathrm{pH} \mathrm{7,} \mathrm{akuades} \mathrm{pH} 7$ dan $\mathrm{CaCl}_{2}$ $1 \%$. Pelarut ditambahkan pada sampel dengan rasio 1:10 (b/v) lalu dihaluskan dengan blender, sehingga diperoleh bentuk pasta. Pasta tersebut diekstrak dengan gelombang ultrasonik frekuensi $40 \mathrm{kHz}$ dengan perlakuan waktu 30 menit pada suhu $4{ }^{\circ} \mathrm{C}$. Hasil ekstraksi kemudian disaring dengan saringan nilon 150 dan kertas saring Whatman No. 42. Selanjutnya dilakukan sentrifugasi sampel dengan kecepatan $12.000 \mathrm{~g}$ pada suhu $4{ }^{\circ} \mathrm{C}$ selama 30 menit dan dipisahkan supernatannya, sehingga dihasilkan ekstrak kasar pigmen fikoeritrin.

\section{Presipitasi pigmen fikoeritrin (Sharmila et al. 2017 dengan modifikasi)}

Ekstrak kasar pigmen fikoeritrin kemudian dipresipitasi dengan amonium sulfat pada saturasi $60 \%$. Ekstrak fikoeritrin dengan amonium sulfat diinkubasi dengan suhu $4{ }^{\circ} \mathrm{C}$ selama 1 jam. Hasil presipitasi disentrifugasi pada $12.000 \mathrm{~g}$, suhu $4{ }^{\circ} \mathrm{C}$ selama 30 menit dan dipisahkan endapannya. Endapan tersebut kemudian didialisis dengan kantong membran ukuran $14 \mathrm{kDa}$ menggunakan akuades sebanyak $1 \mathrm{~L}$ pada suhu $4{ }^{\circ} \mathrm{C}$. Selama proses dialisis dilakukan penggantian akuades setiap 4 jam sekali selama 24 jam.

\section{Analisis kadar air (AOAC 2005)}

Analisis kadar air dilakukan dengan mengacu pada AOAC (2005). Cawan tembikar yang akan digunakan dikeringkan pada suhu $105^{\circ} \mathrm{C}$ selama 3 jam, lalu didinginkan pada desikator. Sebanyak 3 g rumput laut dimasukkan pada cawan tembikar tersebut, kemudian dikeringkan menggunakan oven pada suhu $105^{\circ} \mathrm{C}$ selama 3 jam. Sampel yang telah dikeringkan didinginkan pada desikator, kemudian ditimbang. Perhitungan kadar air dapat dilakukan menggunakan rumus sebagai berikut:

Kadar $\operatorname{air}(\%)=\frac{\text { Bobot sampel basah-bobot sampel kering }}{\text { Bobot sampel kering }} \times 100 \%$

\section{Analisis kadar abu (AOAC 2005)}

Analisis kadar abu dilakukan dengan mengacu pada AOAC (2005). Cawan tembikar yang digunakan dikeringkan dalam oven pada suhu $105^{\circ} \mathrm{C}$ selama 1 jam, kemudian disimpan selama 30 menit dalam desikator hingga dingin dan kadar air konstan kemudian sampel ditimbang. Sebanyak $1 \mathrm{~g}$ sampel dimasukkan ke dalam cawan tembikar dan dimasukkan ke tanur pada suhu $550{ }^{\circ} \mathrm{C}$ selama 6 jam. Cawan kemudian didinginkan dalam desikator dan ditimbang. Perhitungan kadar abu dapat ditentukan menggunakan rumus berikut:

Kadar abu(\%) $=\frac{\text { Bobot abu }}{\text { Bobot sampel }} \times 100 \%$

\section{Analisis lemak kasar (AOAC 2005)}

Sampel sebanyak $2 \mathrm{~g}$ disebar di atas kapas yang beralas kertas saring dan digulung membentuk bidal (thimble), kemudian dimasukkan ke dalam labu soxhlet. Sampel selanjutnya diekstraksi selama 6 jam dengan pelarut lemak berupa n-heksana sebanyak $150 \mathrm{~mL}$. Lemak yang terekstrak dikeringkan menggunakan oven pada suhu $100{ }^{\circ} \mathrm{C}$ selama 1 jam. Perhitungan kadar lemak dapat ditentukan menggunakan rumus berikut:

$\operatorname{Kadar} \operatorname{lemak}(\%)=\frac{\text { Bobot lemak terekstrak }}{\text { Bobot sampel }} \times 100 \%$ 


\section{Analisis protein kasar (AOAC 2005)}

Sampel sebanyak 0,25 g dimasukkan dalam labu Kjeldahl $100 \mathrm{~mL}$ dan ditambahkan selenium $0,25 \mathrm{~g}$ serta $3 \mathrm{~mL} \mathrm{H}_{2} \mathrm{SO}_{4}$ pekat, kemudian dilakukan proses destruksi selama 1 jam hingga larutan jernih. Hasil destruksi yang telah dingin, lalu ditambah dengan $50 \mathrm{~mL}$

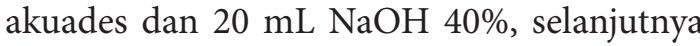
didestilasi. Hasil destilasi ditampung dalam labu Erlenmeyer yang berisi campuran $10 \mathrm{~mL}$ $\mathrm{H}_{3} \mathrm{BO}_{3} 2 \%$ dan 2 tetes indikator bromokresol hijau-metil merah berwarna merah muda. Proses destilasi dihentikan setelah volume hasil destilat menjadi $10 \mathrm{~mL}$ dan berwarna hijau kebiruan. Hasil destilasi kemudian dititrasi dengan $\mathrm{HCl}$ 0,1 $\mathrm{N}$ sampai berwarna merah muda. Perlakuan yang sama juga dilakukan pada blangko. Kadar protein dapat dihitung menggunakan rumus berikut:

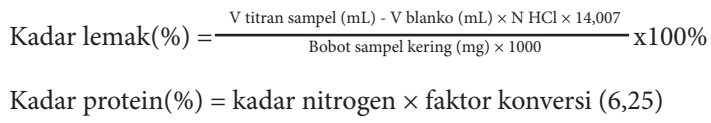

\section{Analisis kadar karbohidrat (by difference)}

Kadar karbohidrat total ditentukan dengan metode karbohidrat by difference. Kadar protein bebas $\mathrm{N}$ menunjukkan besarnya kandungan karbohidrat yang dapat dicerna dari suatu bahan pangan. Kadar karbohidrat dapat dihitung dengan menggunakan persamaan sebagai berikut:

Kadar karbohidrat(\%)=100\%-(kadar air+abu+protein+ lemak $)$

\section{Analisis serat kasar (AOAC 2005)}

Sampel sebanyak $1 \mathrm{~g}$ dilarutkan dengan $100 \mathrm{~mL} \mathrm{H}_{2} \mathrm{SO}_{4} 1,25 \%$, lalu dipanaskan hingga mendidih dan selanjutnya didestruksi selama 30 menit. Hasil destruksi kemudian disaring dengan kertas saring. Residu hasil saringan dibilas dengan 20-30 mL air mendidih dan dibilas dengan $25 \mathrm{~mL}$ air biasa sebanyak 3 kali. Residu didestruksi kembali dengan $\mathrm{NaOH} 1,25 \%$ selama 30 menit, kemudian disaring dan dibilas menggunakan $25 \mathrm{~mL}$ $\mathrm{H}_{2} \mathrm{SO}_{4}$ 1,25\% mendidih, $25 \mathrm{~mL}$ air sebanyak 3 kali, dan $25 \mathrm{~mL}$ alkohol. Residu dan kertas saring dipindahkan ke cawan tembikar dan dikeringkan dalam oven pada suhu $130{ }^{\circ} \mathrm{C}$ selama 2 jam, dan selanjutnya ditimbang. Residu dalam cawan tembikar kemudian dibakar menggunakan tanur pada suhu 600 ${ }^{\circ} \mathrm{C}$ selama 30 menit, lalu didinginkan dan ditimbang kembali. Kadar serat kasar dapat diperoleh menggunakan rumus berikut:

\section{Bobot serat kasar=bobot residu sebelum ditanur - bobot residu setelah ditanur \\ Kadar serat kasar $(\%)=\frac{\text { Bobot serat kasar }}{\text { Bobot sampel }} \times 100 \%$ \\ Analisis konsentrasi dan indeks kemurnian pigmen fikoeritrin (Kursar et al. 1983)}

Analisis konsentrasi dan indeks kemurnian pigmen fikoeritrin dilakukan menggunakan spektrofotometer UV-Vis Shimadzu UV-1700 pada panjang gelombang 200 sampai $700 \mathrm{~nm}$. Kemurnian indeks fikoeritrin dapat ditentukan dengan rasio perbandingan A565/A280. Konsentrasi fikobiliprotein dapat dihitung menggunakan persamaan berikut:

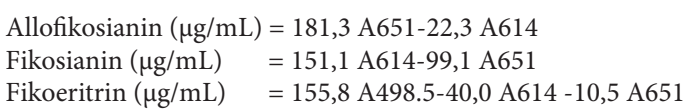

\section{Analisis profil protein dengan SDS-Page (Laemmli 1970 dengan modifikasi)}

Analisis profil protein pada pigmen fikoeritrin dilakukan menggunakan sodium dodecyl sulphate polyacrilamide gel electrophoresis (SDS-PAGE). Analisis dilakukan dengan beberapa tahap, yaitu pembuatan gel SDS-PAGE, preparasi sampel, dan elektroforesis. Identifikasi dan analisis pola SDS-PAGE dilakukan dengan membandingkan pita protein sampel dengan protein standar. Bobot molekul masingmasing protein ditentukan menggunakan perangkat lunak Photocapt.

Penentuan bobot molekul dan susunan protein dianalisis menggunakan SDS-PAGE. SDS-PAGE dilakukan menggunakan gel pengumpul (stacking gel) 3\% akrilamida dan gel pemisah (separating gel) 12,5\% akrilamida. Sampel sebanyak $10 \mu \mathrm{L}$ ditambahkan 10 $\mu \mathrm{L}$ sampel bufer didenaturasi pada suhu $95{ }^{\circ} \mathrm{C}$ selama 10 menit. Sampel yang telah terdenaturasi dimasukkan ke dalam sumur gel akrilamida. Protein marker yang digunakan memiliki bobot molekul 10-250 $\mathrm{kDa}$. Elektroforesis dilakukan pada tegangan 170 V selama 60 menit. Selanjutnya dilakukan 
pewarnaan gel menggunakan comassiebrilliant blue ( $\mathrm{CBB}$ ) dan penghilangan pewarna yang tidak terikat pada protein, sehingga pita-pita protein yang terbentuk dapat terlihat jelas.

\section{Analisis data}

Analisis data yang digunakan pada penelitian ini yaitu rancangan acak lengkap (RAL) dengan perlakuan pelarut yang berbeda. Masing-masing perlakuan diulang sebanyak 3 kali. Data dianalisis menggunakan metode analisis ragam (ANOVA). Apabila data menunjukkan signifikan atau berbeda nyata $(p<0,05)$, maka data diuji lanjut menggunakan uji Duncan.

\section{HASIL DAN PEMBAHASAN Komposisi kimia K. alvarezii}

Eucheuma cottonii adalah salah satu spesies rumput laut merah (Rhodophyta) yang berganti nama menjadi $K$. alvarezii karena karagenan yang dihasilkan merupakan fraksi kappa-karagenan (Anggadiredja et al. 2006). $K$. alvarezii mempunyai talus silindris, permukaan licin, menulang rawan (cartilaginous). Warna dapat berubah-ubah, antara hijau, pistachio (hijau kekuningan), atau merah. Warna yang berubah terjadi akibat pengaruh lingkungan dan merupakan suatu proses adaptasi kromatik yaitu penyesuaian antara proporsi pigmen dengan berbagai kualitas pencahayaan (Niu et al. 2006). Tumbuh melekat ke substrat dengan alat perekat berupa cakram. Umumnya K. alvarezii tumbuh dengan baik di daerah pantai terumbu (reef). Habitat khasnya adalah daerah yang memperoleh aliran air laut yang tetap, variasi suhu harian yang kecil dan substrat batu karang mati (Tandeau 2003).

Kadar air rumput laut $K$. alvarezii yang diperoleh dari perairan Desa Lontar 79,09\% (bb), lebih rendah jika dibandingkan dengan $K$. alvarezii yang diperoleh dari Langkawi, Malaysia 86,8\% (bb) (Xiren dan Aminah (2017). Hal ini dapat disebabkan oleh perbedaan spesies, lokasi, temperatur musiman, kondisi panen, dan umur panen (Hardjani et al. 2017).

Rumput laut $K$. alvarezii yang diperoleh dari perairan Desa Lontar memiliki kadar abu 5,74\% (bb) atau 27,42\% (bk), hampir sama jika dibandingkan dengan rumput laut K. alvarezii yang diperoleh dari Pantai Barat Provinsi Santa Elena, Ekuador yang memiliki kadar abu 27,49\% (bk). Namun lebih rendah jika dibandingkan kadar abu dari perairan Langkawi, Malaysia 16,3\% (bb). Syafar et al. (2019) mendapatkan kadar abu pada rumput laut K. alvarezii 3,44\%-3,30\%. Abu merupakan zat anorganik sisa hasil pembakaran suatu bahan organik. Hal ini disebabkan oleh habitat rumput laut di perairan laut yang kaya akan mineral (Gebhardt dan Thomas 2002).

Kadar lemak yang diperoleh pada rumput laut $K$. alvarezii dari perairan Desa Lontar 0,81\% (bk), Pantai Barat Provinsi Santa Elena, Ekuador $0,57 \%$ (bk), Perairan Langkawi, Malaysia $1,0 \%$ (bk). Perbedaan kandungan lemak pada spesies yang sama dapat disebabkan oleh letak geografis asal spesies dan kualitas air laut (Marinho-Soriano et al. 2006; Zawawi et al. 2014).

Protein kasar pada rumput laut merah (Rhodophyta) umumnya lebih tinggi dari jenis rumput laut cokelat dan hijau (Cerna 2011). Kadar protein kasar pada rumput laut $K$. alvarezii yang diperoleh dari perairan Desa Lontar, yaitu 5,78\% (bk), Pantai Barat Provinsi Santa Elena, Ekuador 4,86\% (bk), perairan Langkawi, Malaysia 6,2\% (bk). Rendahnya kadar protein pada penelitian ini dipengaruhi oleh kondisi lingkungan serta waktu pemanenan rumput laut. Munier et al. (2013) menjelaskan bahwa kondisi lingkungan hidup, yakni gelombang dan arus laut dapat menjadi alasan bervariasinya nilai komposisi kimia rumput laut, termasuk kadar protein itu sendiri. Faktor lainnya dapat disebabkan oleh kondisi iklim, misalnya suhu, salinitas, dan intensitas cahaya yang diterima oleh rumput laut dilaporkan dapat pula memengaruhi nilai komposisi kimia rumput laut (Renaud dan Luong-Van 2006). Kadar protein kasar pada bahan rumput laut merah yang akan diekstraksi nantinya akan memengaruhi konsentrasi fikoeritrin yang dihasilkan.

Karbohidrat rumput laut $K$. alvarezii yang diperoleh dari perairan Desa Lontar 65,98\% (bk), lebih tinggi jika dibandingkan dengan karbohidrat rumput laut $K$. alvarezii yang diperoleh dari Pantai Barat Provinsi Santa Elena, Ekuador 41,15\% (bk). Variasi 
kadar karbohidrat dapat dipengaruhi oleh faktor perbedaan aktivitas fotosintesis, tahap pertumbuhan, dan musim yang merupakan hasil dari perubahan lingkungan yang dapat memengaruhi fotosintesis dan penyerapan nutrisi (Wong dan Cheung 2000).

Serat kasar rumput laut $K$. alvarezii yang diperoleh dari Perairan Desa Lontar 5,25\% (bk). Nilai serat kasar pada rumput laut dapat dipengaruhi oleh kondisi pembudidayaan, spesies dan musim (Dumay et al. 2014). Analisis komposisi kimia rumput laut K. alvarezii dapat dilihat pada Table 1 .

\section{Ekstraksi Pigmen Fikoeritrin dengan Pelarut Berbeda Spektrum absorbansi fikoeritrin}

Fikoeritrin adalah pigmen paling dominan pada alga merah. Semakin bertambahnya kedalaman laut, kandungan pigmen fikoeritrin semakin bertambah. Hal tersebut terjadi karena rendahnya kandungan klorofil a, sehingga memicu pembentukan fikoeritrin yang akan digunakan untuk membantu penyerapan cahaya pada proses fotosintesis (Mizuno 1986). Berdasarkan serapan spektra, fikoeritrin dibagi menjadi beberapa jenis. Salah satunya adalah R-fikoeritrin (R-PE) yang merupakan jenis fikobiliprotein pendominasi alga merah (Marsac 2003) yang mempunyai dua tipe kromofor s (sensitizing) dan $\mathrm{f}$ (fluorescing) dengan nilai absorbansi maksimal sekitar $580 \mathrm{~nm}$ (Tandeau 2003). Struktur subunit fikoeritrin adalah $(\alpha \beta) 6 \gamma$ dan mempunyai berat molekul $240 \mathrm{kDa}$ (Rossano et al. 2003). Ekstrak pigmen fikoeritrin memiliki kenampakan berwarna merah muda seperti yang tampak pada Figure 1a. Pelarut akuades dan bufer fosfat menghasilkan warna pigmen lebih pekat dibandingkan dengan ekstraksi pigmen menggunakan pelarut $\mathrm{CaCl}_{2}$.

Fikoeritrin dapat diukur pada rentang panjang gelombang 400-650 nm (Dumay et al. 2014). Puncak-puncak absorbansi teridentifikasi pada panjang gelombang 498, 534 dan 564, khas dari fikoeritrin. Puncak tersebut teridentifikasi dengan jelas terutama pada pigmen yang diperoleh menggunakan pelarut akuades. Adapun spektrum absorbansi panjang gelombang pada fikoeritrin dapat dilihat pada Figure $1 b$.

\section{Konsentrasi dan indeks kemurnian fikoeritrin}

Ekstrak pigmen fikoeritrin $K$. alvarezii menggunakan akuades menunjukkan konsentrasi tertinggi $0,057 \mathrm{mg} / \mathrm{mL}$. Konsentrasi fikoeritrin ini tidak jauh berbeda jika dibandingkan dengan penelitian Hidhayati et al. (2020) yaitu fikobiliprotein (jenis fikoeritrin) dari sianobakteria $C$. turgidus dengan konsentrasi pigmen $0,032 \mathrm{mg} /$ $\mathrm{mL}$ didapatkan dari ekstraksi menggunakan pelarut air. Pelarut air aman digunakan untuk mengekstraksi fikobiliprotein dan dapat menarik zat-zat aktifnya karena air tidak memiliki daya toksik dan lebih ekonomis dibandingkan dengan jenis pelarut lainnya (Farihah et al. 2014).

Table 1 Chemical composition K. alvarezii

\begin{tabular}{|c|c|c|c|c|}
\hline \multirow{2}{*}{ Parameter } & \multicolumn{2}{|c|}{ Lontar, Banten } & \multirow{2}{*}{$\begin{array}{l}\text { West Coast of Santa } \\
\text { Elena Province, Ecuador } \\
\text { (db) }\end{array}$} & \multirow{2}{*}{$\begin{array}{l}\text { Langkawi, } \\
\text { Malaysia }^{\mathrm{b}}\end{array}$} \\
\hline & $(w b)$ & $(\mathrm{db})$ & & \\
\hline Moisture (\%) & $79.09 \pm 0.00$ & & & $86.8 \pm 0.70(w b)$ \\
\hline Ash (\%) & $5.74 \pm 0.02$ & 27.42 & $27.49 \pm 0.15$ & $16.3 \pm 0.05(\mathrm{wb})$ \\
\hline Fat (\%) & $0.17 \pm 0.02$ & 0.81 & $0.57 \pm 0.01$ & $1.0 \pm 0.60(\mathrm{db})$ \\
\hline Protein (\%) & $1.21 \pm 0.05$ & 5.78 & $4.86 \pm 0.01$ & $6.2 \pm 0.40(\mathrm{db})$ \\
\hline Carbohydrate (\%) & $13.81 \pm 0.03$ & 65.98 & & \\
\hline Crude fiber (\%) & $1.10 \pm 0.11$ & 5.25 & $3.18 \pm 0.11$ & $7.8 \pm 0.60(\mathrm{db})$ \\
\hline
\end{tabular}




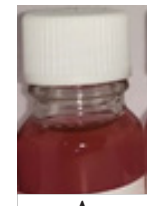

A
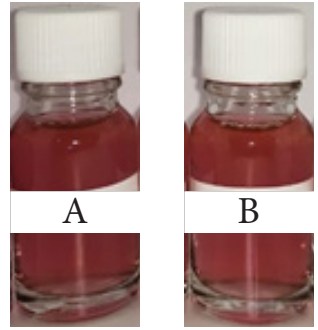

(a)

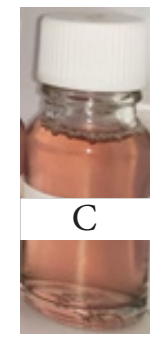

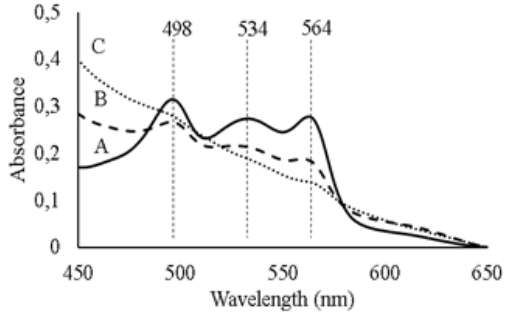

(b)

Figure 1 (a) Extract phycoerytrin pigments and (b) maximum absorbance spectrum of phycoerytrin using (A) aquadest $\mathrm{pH} 7,(\mathrm{~B})$ buffer phosphate $0.1 \mathrm{M} \mathrm{pH} 7,(\mathrm{C}) \mathrm{CaCl}_{2} 1 \%$, with 30 minutes extraction time

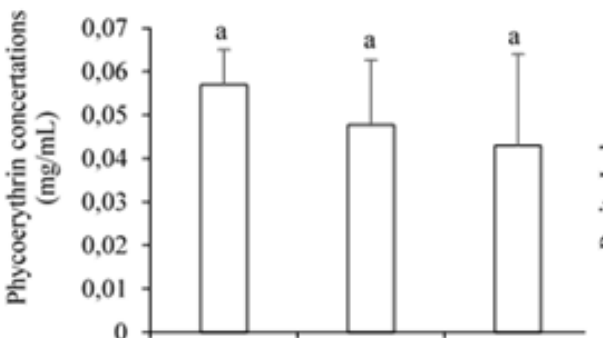

(A)

(B)

(C)

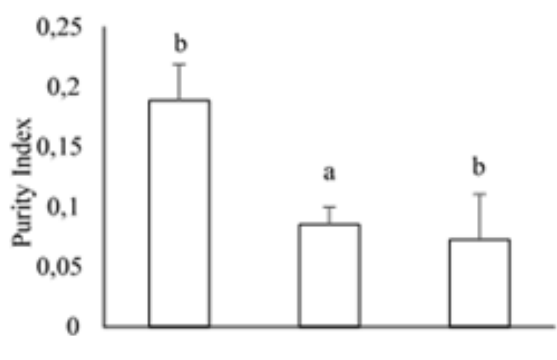

(A)

(B)

(C)

Figure 2 Phycoerythrin concentrations and purity index of $K$. alvarezii extract with different solvent; (A) aquadest pH7; (B) buffer phosphate $0.1 \mathrm{M}$; (C) $\mathrm{CaCl}_{2} 1 \%$.

Indeks kemurnian menentukan aplikasi dari ekstrak yang diperoleh (Charrier et al. 2018). Indeks kemurnian ekstrak pigmen fikoeritrin $K$. alvarezii tertinggi diperoleh pada ekstraksi menggunakan akuades dengan nilai 0,189 terlihat pada Figure 2. Indeks kemurnian tersebut masih berada pada rentang indeks kemurnian ekstrak kasar fikoeritrin yang diperoleh pada penelitian Uju et al. (2020) 0,054-1,121 mg/mL. Fikoeritrin dikategorikan food grade apabila indeks kemurniannya di atas 0,7 dan drug class jika lebih dari 2 (Pan et al. 2013).

\section{Histologi Jaringan K. alvarezii}

Rumput laut merah mempunyai kenampakan warna talus yang bervariasi. Warna talus yang bervariasi disebabkan adanya komposisi pigmen yang terdiri dari klorofil a, klorofil d, dan fikobiliprotein (R-fikosianin, allofikosianin serta fikoeritrin) (Lee 2008).Talus $K$. alvarezii terdiri dari jaringan penyusun yaitu epidermis, lapisan pseudoparenkim dan medula, yang memiliki fungsi yang berbeda. K. alvarezii tergolong multiseluler, setiap selnya mengandung satu atau lebih kloroplas yang dapat berbentuk pita atau seperti cakram-cakram diskret. Di dalam matriks kloroplas terdapat gelembunggelembung pipih bermembran yang dinamakan membran tilakoloid. Membran tilakoloid berisikan klorofil dan pigmenpigmen pelengkap. Pada membran tilakoid alga merah, fikobiliprotein membentuk antena di permukaan stromal (Kawsar et al. 2011).

Pada Figure 3b, K. alvarezii yang telah diekstraksi menggunakan akuades dan bantuan ultrasonik terlihat mengalami perubahan bentuk jaringan dari yang semula kokoh menjadi berkerut. Hal ini ditunjukkan oleh histologi jaringan rumput laut $K$. alvarezii sehat yang memiliki sel-sel berbentuk bulat lonjong pada bagian luar dinding talus dan akan semakin membesar pada bagian tengah talus serta tersusun tidak beraturan (Darmawati 2012). Jaringan rumput laut $K$. alvarezii varietas cokelat dengan bentuk sel yang sehat menunjukkan bagian korteks yang teratur dan tidak renggang (antar dinding sel rapat) (Maulani et al. 2017). Namun banyaknya rongga mikro yang dihasilkan oleh ultrasonik mampu membantu memecahkan dinding sel 

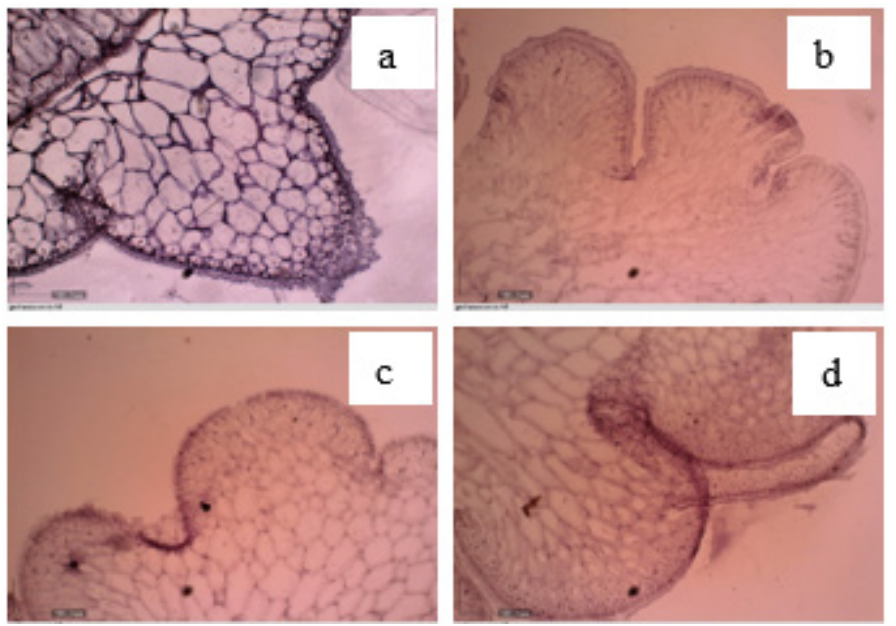

Figure 3 Cross-section of $K$. alvarezii seaweed a) without treatment b) maceration using aquadest $\mathrm{pH} 7 \mathrm{c}$ ) maceration using buffer phosphate $0.1 \mathrm{M} \mathrm{pH} 7 \mathrm{~d}$ ) maceration using $\mathrm{CaCl}_{2} 1 \%$.
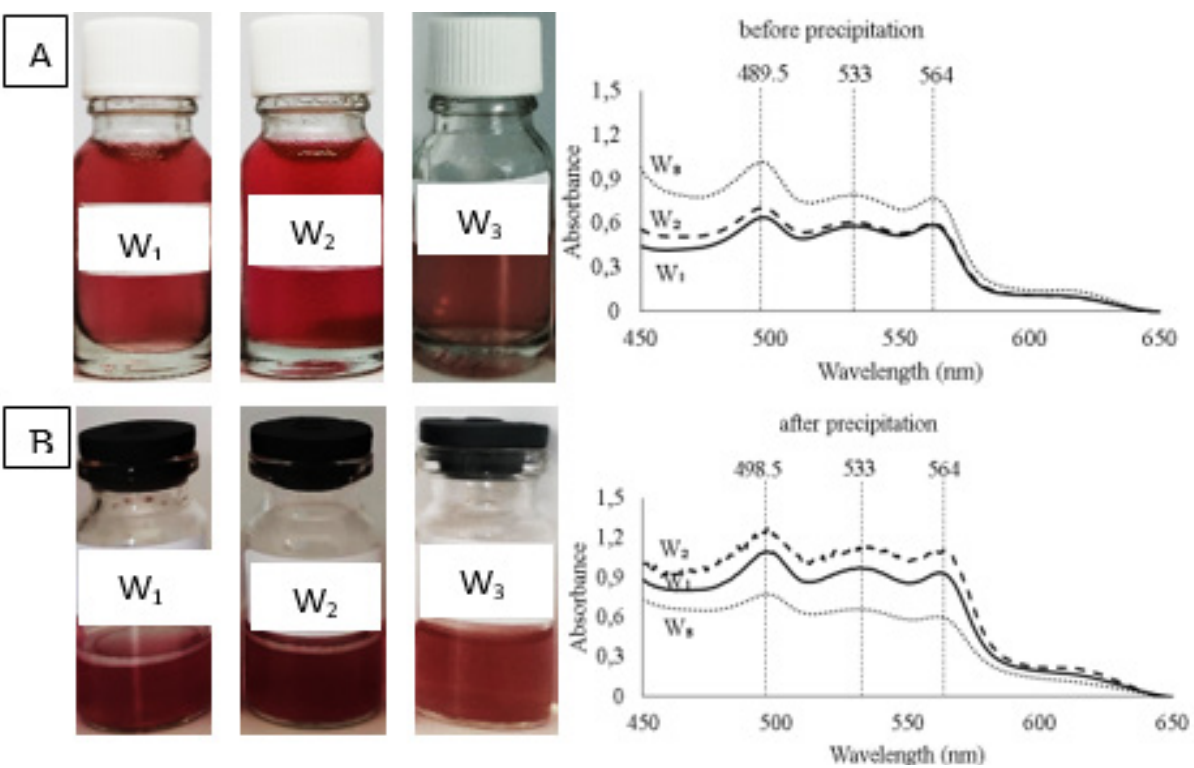

Figure 4 A) Extraction of phycoerythrin and maximum absorbance spectrum of phycoerythrin pigment before precipitation; B) extraction of phycoerythrin and maximum absorbance spectrum of phycoerythrin pigment after precipitation using aquadest $\mathrm{pH} 7$ with extraction time $\left(\mathrm{W}_{1}\right) 35$ minutes, $\left(\mathrm{W}_{2}\right) 45$ minutes, $\left(\mathrm{W}_{3}\right) 55$ minutes

(Shirsath et al. 2012), sehingga peningkatan kecepatan kontak antara bahan dan pelarut membantu peningkatan penetrasi cairan menuju dinding sel dan melepas komponen sel (Wang et al. 2011).

\section{Ekstraksi Pigmen Fikoeritrin dengan Lama Waktu Berbeda Kenampakan dan spektrum absorbansi fikoeritrin}

Ekstraksi pigmen fikoeritrin dilakukan menggunakan bantuan ultrasonik dengan lama waktu ekstraksi berbeda yaitu 35 menit (W1), 45 menit (W2), dan 55 menit (W3). Dari hasil ekstraksi pada Figure 4A, dapat dilihat bahwa ekstrak pigmen fikoeritrin W1 dan W2 berwarna merah pekat jika dibandingkan dengan W3 yang memiliki warna merah lebih muda. Hal ini dapat disebabkan oleh pengaruh ultrasonik dan lama waktu ekstraksi yang digunakan. Ultrasonik merupakan metode ekstraksi non termal yang dapat meningkatkan laju transfer massa serta memecahkan dinding sel dengan banyaknya rongga 
mikro sehingga akan mempersingkat waktu proses dan mengoptimalkan penggunaan pelarut (Shirsath et al. 2012). Peningkatan kecepatan kontak antara ekstrak dan solven menyebabkan peningkatan penetrasi cairan menuju dinding sel dan melepas komponen sel (Wang et al. 2011). Kelebihan metode UAE (Ultrasonic Assisted Extraction) adalah dapat mengeluarkan ekstrak dari matriks tanpa merusak merusak struktur jaringan (Babaei et al. 2006).

Presipitasi amonium sulfat biasa digunakan sebagai tahap awal dalam proses purifikasi protein dengan persen saturasi yang bergantung pada jenis protein (Dumay et al. 2014). Dapat dilihat pada Figure $4 B$ bahwa ekstrak yang telah mengalami presipitasi menghasilkan warna yang lebih pekat. Hal ini karena adanya proses pemekatan. R-PE memiliki serapan maksimal pada 498 $\mathrm{nm}$, untuk mendeteksi phycourobilin dan pada $545 \mathrm{~nm}$ dan $565 \mathrm{~nm}$, untuk kromofor fikoeritrobilin (Kursar et al. 1983). Puncak serapan spektrum teridentifikasi pada Panjang gelombang 498,5 nm, $533 \mathrm{~nm}$ dan $564 \mathrm{~nm}$. Dapat dilihat pada Figure 4, serapan spektrum fikoeritrin mengalami penurunan absorbansi pada lama waktu ekstraksi 55 menit (W3).

\section{Konsentrasi dan indeks kemurnian fikoeritrin}

Ekstraksi setelah presipitasi dapat dilihat pada Figure 5. Ekstraksi sebelum presipitasi menunjukkan konsentrasi pigmen fikoeritrin tertinggi $0,315 \mathrm{mg} / \mathrm{mL}$ dengan lama waktu ekstraksi 55 menit. Konsentrasi pigmen fikoeritrin setelah presipitasi mengalami peningkatan dengan nilai tertinggi 0,421 $\mathrm{mg} / \mathrm{mL}$ dengan lama waktu ekstraksi 45

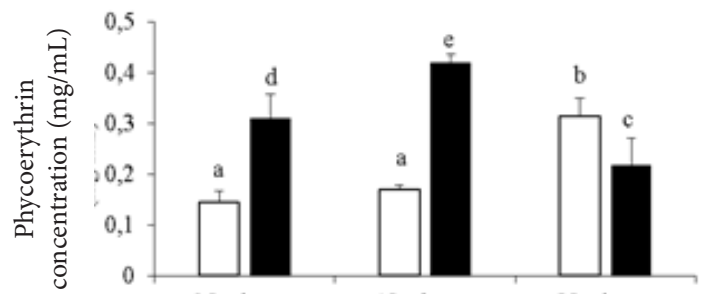

(A)
(B) menit. Uju et al. (2020) melaporkan bahwa ekstrak kasar fikoeritrin sebelum presipitasi meningkat dari $0,054 \mathrm{mg} / \mathrm{mL}$ sampai 1,121 $\mathrm{mg} / \mathrm{mL}$ dan mengalami peningkatan setelah dilakukan presipitasi.

Indeks kemurnian pigmen fikoeritrin dapat dilihat pada Figure 5. Ekstraksi sebelum presipitasi menunjukkan indeks kemurnian pigmen fikoeritrin tertinggi $0,613 \mathrm{mg} / \mathrm{mL}$ dengan lama waktu ekstraksi 55 menit. Indeks kemurnian tersebut masih berada pada rentang indeks kemurnian ekstrak kasar fikoeritrin yang diperoleh pada penelitian Uju et al. (2020) 0,1946-0,2255. Indeks kemurnian pigmen fikoeritrin setelah presipitasi meningkat dan menghasilkan nilai tertinggi $0,831 \mathrm{mg} / \mathrm{mL}$ dengan lama waktu ekstraksi 45 menit. Hal ini didukung oleh penelitian Uju et al. (2020) bahwa indeks kemurnian fikoeritrin setelah presipitasi dapat mengalami peningkatan 3-6 kali dari indeks kemurnian ekstrak kasar fikoeritrin dengan nilai 0,6905-1,2445. Rossano et al. (2003) menyebutkan bahwa pigmen fikoeritrin dapat dikatakan murni apabila indeks kemurnian yang dimiliki lebih dari 5,3.

Secara keseluruhan, pigmen fikoeritrin sebelum presipitasi mengalami kenaikan nilai konsentrasi. Setelah dilakukan presipitasi, konsentrasi pigmen fikoeritrin mengalami penurunan pada lama waktu ekstraksi 55 menit. Hal ini karena adanya komponen lain dari $K$. alvarezii yang terekstrak saat proses ekstraksi menggunakan bantuan ultrasonik. Efek mekanik dari gelombang ultrasonik yang ditimbulkan akan meningkatkan penetrasi dari cairan menuju dinding membran sel, mendukung pelepasan komponen sel dan meningkatkan transfer

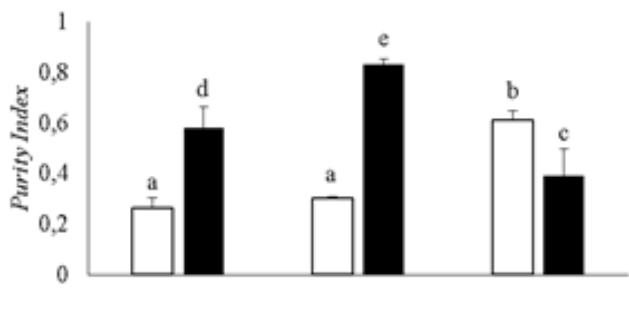

(A)
(B)

Figure 5 Phycoerythrin pigment concentration and purity index using aquadest $\mathrm{pH} 7$ with different extraction time; (A) 35 minutes; (B) 45 minutes; (C) 55 minutes; $\square$ before precipitation; after precipitation. 
massa (Handaratri dan Yuniati 2019). Hal tersebut disebabkan gelombang ultrasonik menghasilkan gelombang kavitasi yang diduga mampu meningkatkan efektivitas perpindahan massa ke titik pusat dalam waktu singkat (Balachandran et al. 2006). Widyasanti et al. (2008) melaporkan pada perlakuan amplitudo 95\% dengan waktu ekstraksi 45 menit yang berhenti mengalami kenaikan kuantitas senyawa yang terekstrak dan nilai antosianinnya menurun. BermúdezAguirre et al. (2011) melaporkan bahwa waktu ekstraksi yang tepat akan menghasilkan senyawa yang optimal.

\section{Aktivitas antioksidan pigmen fikoeritrin}

Fikoeritrin merupakan antioksidan alami yang dapat membantu menguraikan radikal bebas dalam tubuh karena kerusakan sel (Bulimaga et al. 2018). Aktivitas antioksidan pada pigmen fikoeritrin ditentukan salah satunya dengan metode DPPH (1,1-difenil2-pikrilhidrazil). Hal ini sesuai dengan pernyataan Sangeetha et al. (2017) bahwa pengujian aktivitas antioksidan pada pigmen fikoeritrin akan memberikan scavenging effect yang sangat bagus dengan metode DPPH. Persen inhibisi DPPH menunjukkan aktivitas scavenging radical/peredam radikal bebas yang dimiliki setiap sampel.
Dapat dilihat pada Table 2, persen inhibisi aktivitas antioksidan tertinggi pigmen fikoeritrin dihasilkan oleh perlakuan lama waktu ekstraksi 45 menit (W2) dengan konsentrasi $80 \mathrm{ppm}$ dan aktivitas antioksidan 89\%. Sangeetha et al. (2017) melaporkan R-fikoeritrin memberikan scavenging effect yang sangat bagus dengan metode DPPH. R-fikoeritrin dengan konsentrasi $50 \mu \mathrm{g} / \mathrm{ml}$ menunjukkan aktivitas antioksidan $60,71 \%$. Persen inhibisi pigmen fikoeritrin masih tergolong lebih rendah jika dibandingkan dengan standar asam askorbat. Jika ingin mencapai aktivitas antioksidan pada kisaran lebih dari 40\%, maka konsentrasi asam askorbat yang dibutuhkan lebih kurang 4,5 ppm. Pada pigmen fikoeritrin, jika ingin mendapatkan aktivitas antioksidan pada kisaran lebih dari 40\%, maka konsentrasi pigmen fikoeritrin yang dibutuhkan lebih kurang 50 ppm.

\section{Profil protein pigmen fikoeritrin}

Analisis profil protein pigmen fikoeritrin $K$. alvarezii dilakukan menggunakan Sodium Dodecyl Sulphate Polyacrilamide Gel Elektroforesis (SDS-PAGE). Prinsip dasar metode ini adalah denaturasi protein oleh SDS dengan separasi molekul berdasarkan berat molekulnya dengan metode elektroforesis

Table 2 Antioxidant activity (\% Inhibition) of sample and standard of ascorbic acid

\begin{tabular}{lrrr}
\hline Sample & $\begin{array}{c}\text { Sample } \\
\text { concentration } \\
(\mathrm{ppm})\end{array}$ & Absorbance & $\begin{array}{c}\text { Antioxidant } \\
\text { activity }(\% \\
\text { Inhibition) }\end{array}$ \\
\hline & 1.5 & 0.290 & $18 \%$ \\
Ascorbic acid & 2.5 & 0.256 & $28 \%$ \\
& 3.5 & 0.228 & $36 \%$ \\
& 4.5 & 0.207 & $42 \%$ \\
Phycoerythrin & 5.5 & 0.178 & $50 \%$ \\
W & 50.0 & 0.124 & $43 \%$ \\
\hline Phycoerythrin & 80.0 & 0.069 & $68 \%$ \\
$\mathrm{~W}_{2}$ & 50.0 & 0.084 & $62 \%$ \\
\hline Phycoerythrin & 80.0 & 0.025 & $89 \%$ \\
$\mathrm{~W}_{3}$ & 50.0 & 0.083 & $62 \%$ \\
\hline
\end{tabular}

Note: $\mathrm{W}_{1}=$ extraction time 35 minutes, $\mathrm{W}_{2}=$ extraction time 45 minutes, $\mathrm{W}_{3}=$ extraction time 55 minutes 


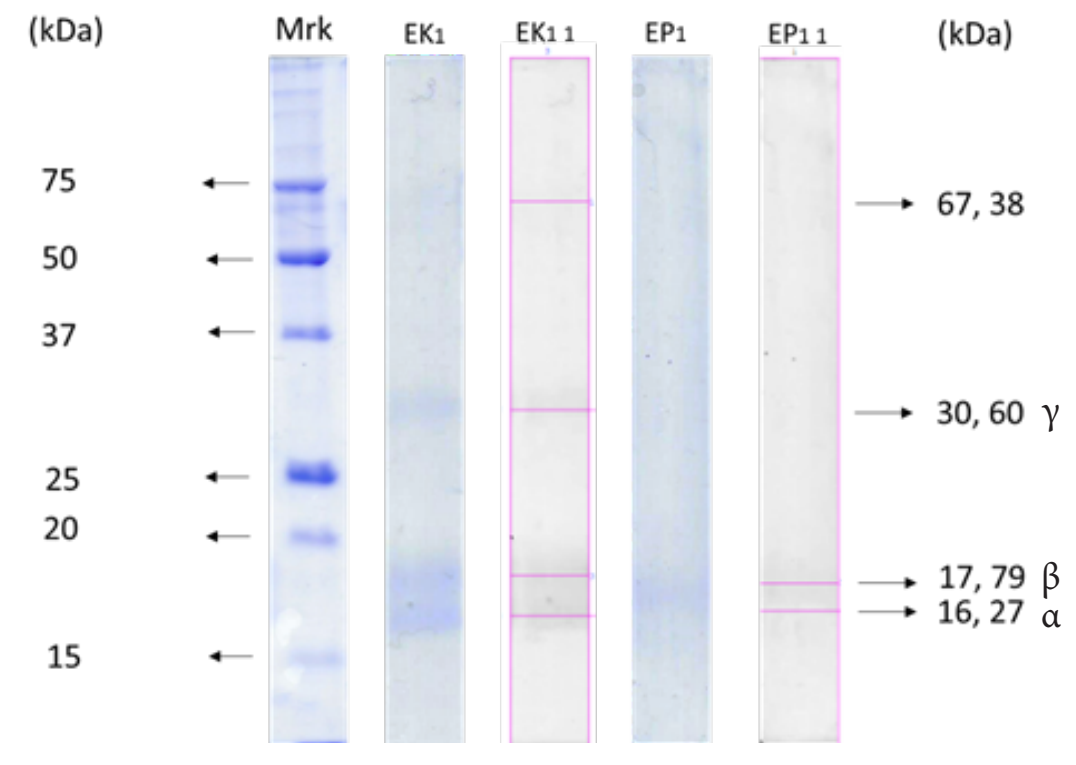

Figure 6 SDS-PAGE profile of phycoerythrin pigment; Mrk=marker, EK=crude extract, EK1 $1=$ crude extract, EP1=extract after precipitation, EP1 1=extract after precipitation

menggunakan gel poliakrilamida. Bila protein tersebut ditransfer ke dalam gel dan dielektroforesis menggunakan listrik, protein bermigrasi menembus poripori gel poliakrilamida. Protein akan berpisah berdasarkan ukuran molekul (Germanyta et al. 2016). Tingkat kemurnian suatu protein juga dapat dilihat dari elektroforegram SDS-PAGE berupa pitapita protein. Semakin banyak pita-pita protein yang terbentuk, menunjukkan bahwa protein tersebut belum murni. Konsentrasi protein ekstrak memengaruhi kualitas pita protein yang terbentuk pada proses analisis karakteristik protein dan kecepatan pembentukan pita protein (Budhy 2004).

Hasil pendugaan protein pada Figure 6 menunjukkan bahwa pigmen fikoeritrin memiliki bobot $16 \mathrm{kDa}$ (subunit $\alpha$ ), 17 $\mathrm{kDa}$ (subunit $\beta$ ), dan $30 \mathrm{kDa}$ (subunit $\gamma$ ). Isailovic et al. (2004) melaporkan bahwa, R-PE dari alga merah Gelidium coulteri memiliki struktur $(\alpha \beta) 6 \gamma$ dan massa molekul $(\mathrm{Mr} \approx 240.000$. Dua subunit yang berbeda dalam urutan asam amino ditemukan dalam protein ini. Subunit a $(\mathrm{Mr} \approx 17.000)$ berisi dua kromofor PEB; subunit $\beta(\mathrm{Mr} \approx 18.000)$ berisi dua PEB dan satu kromofor PUB, sedangkan subunit $\gamma(\mathrm{Mr} \approx 30.000)$ berisi tiga $\mathrm{PUB}$ dan satu kromofor PEB.

\section{KESIMPULAN}

Ekstraksi pigmen fikoeritrin dari rumput laut $K$. alvarezii menggunakan bantuan ultrasonik berpengaruh terhadap hasil ekstrak pigmen yang didapatkan. Hasil menunjukkan bahwa ekstrak pigmen fikoeritrin K. alvarezii menggunakan akuades menghasilkan warna pigmen lebih pekat. Perlakuan terbaik terdapat pada lama waktu ekstraksi 45 menit. Konsentrasi fikoeritrin mengalami peningkatan setelah dilakukan presipitasi dengan nilai tertinggi $0,421 \mathrm{mg} /$ $\mathrm{mL}$ sedangkan indeks kemurnian pigmen fikoeritrin mengalami peningkatan setelah dilakukan presipitasi dengan nilai tertinggi 0,831 . Aktivitas antioksidan (\%inhibisi) terbaik dihasilkan pada konsentrasi 80 ppm $89 \%$.

\section{DAFTAR PUSTAKA}

Anggadiredja, Jana T, Zatnika A, Purwoto H, Istini S. 2006. Rumput Laut. Jakarta (ID): Penebar Swadaya.

[AOAC] Association of Official Analytical Chemist. 2005. Official methods of analysis (18 edn). Mayland (US): AOAC Inc.

Babaei R, Jabbari A, Yamini Y. 2006. Solidliquid extraction of fatty acids of some variety of iranian rice in closed vessel in the absence and presence of ultrasonic 
waves. Asian Journal of Chemistry. 18(1): 57-64.

Balachandran S, Kentish SE, Mawson R, Ashokkumar M. 2006. Ultrasonic enhancement of the supercritical extraction from ginger. Ultrason Sonochem. 13(6): 471-249.

Barsanti L, Gualtieri P. 2006. Algae, Anatomy, Biochemistry, and Biotechnology. Boca Raton (US): CRC Press.

Bermúdez-Aguirre D, Mawson R, BarbosaCánovas GV. 2011. Study of possible mechanisms of inactivation of Listeria innocua in thermo-sonicated milk using scanning electron microscopy and transmission electron microscopy. Journal of Food Processing and Preservation. 35(2011): 767-777.

Budhy TI. 2004. Karsinogenesis karsinoma sel skuamosa rongga mulut yang terinfeksi epstein-barr virus (ebv) berdasar ekspresi p53, c-myc dan bcl-2. [TESIS]. Program Pasca Sarjana Universitas Airlangga. Surabaya.

Bulimaga V, Zosim L, Elenciuc D, Rudic V, Bacalov I, Crivoi A. 2018. Study of the action of chromium-containing biopreparations from Spirulina on insulin activity in rats. Biological Markers in Fundamental and Clinical Medicine. 2(2): 81-82.

Cerna M. 2011. Seaweeds protein and amino acids nutraceutical. Advanced in Food and Nutrition Research. 64: 297-312.

Charrier B, Wichard T, Reddy CRK. 2018. Protocols for Macroalgae Research 1st Edition. Boca Raton (US): Taylor \& Francis Group, CRC Press

D' Alessandro EBD, Antoniosi NR. 2016. Concepts and studies on lipid and pigments of microalgae: a Review. Renewable and Sustainable Energy Revi ews. 58(C): 832-841.

D’Armas H, Jaramillo C, D'Armas $M$, Echavarría A, Valverde P. 2019. Proximate composition of several green, brown and red seaweeds from the coast of Ecuador. Revista de Biología Tropical. 67(1): 61-68.

Darmawati. 2012. Perubahan sel rumput laut Kappaphycus alvarezii yang dibudidayakan pada kedalaman berbeda. Octopus: Jurnal Ilmu Perikanan. 1(2): 6569.

Dumay J, Morancais M, Munier M, Guillard CL, Fleurence J. 2014. Phycoerythrins: valuable proteinic pigments in red seaweeds. Advances in Botanical Research. 71(11): 321-331.

El-aty AMA, Mohamed AA, Samhan FA. 2014. In vitro antioxidant and antibacterial activities of two fresh water Cyanobacterial species, Oscillatoria agardhii and Anabaena sphaerica. Journal of Applied Pharmaceutical Science. 4(07): 69-75.

Farihah S, Yulianto B, Yudiati E. 2014. Penentuan kandungan pigmen fikobiliprotein ekstrak Spirulina platensis dengan teknik ekstraksi berbeda dan uji toksisitas metode bslt. Journal of Marine Research Universitas Diponegoro. 3(2): 140-146.

Fretes, de H, AB Susanto, Budhi P, Heriyanto, Tatas HP, Brotosudarmo, Limantara L. 2012. Estimasi produk degradasi ekstrak kasar pigmen alga merah Kappaphycus alvarezii (doty) doty varian merah, cokelat, dan hijau: Telaah perbedaan spektrum serapan. Ilmu Kelautan. 17(1): 31-38.

Germanyta AA, Jularso E, Budhy TI. 2016. The identification of periapical granuloma protein using SDS-PAGE method. Journal of Oral and Maxillofacial Pathology. 3(1): 11-16.

Gebhardt SE, Thomas RG. 2002. Nutritive value of food. Agricultural Research Service. Beltsville (US): US Department of Agriculture.

Graham LE, Wilcox LW. 2000. Algae. Upper Saddle River (NJ): Prentice Hall.

Handaratri A, Yuniati Y. 2019. Kajian ekstraksi antosianin dari buah murbei dengan metode sonikasi dan microwave. Reka Buana : Jumal Ilmiah Teknik Sipil dan Teknik Kimia 4(1): 63.

Hardjani, K.D, Suantika, G, Aditiawati, P. 2017. Nutritional profile of red seaweed Kappaphycus alvarezii after fermentation using Saccharomyces cerevisiae as a feed 
supplement for white shrimp Litopenaeus vannamei nutritional profile of fermented red seaweed. Journal of Pure and Applied Microbiology. 11(4):1637-1645.

Hemwimol S, Pavasant P, Shotipruk A. 2006. Ultrasound-assisted extraction of anthraquinones from roots of Morinda citrifolia. Ultrasonics Sonochemistry. 13(6): 543-548.

Hidhayati N, Agustini NWS, Apriastini M, Margaretha C. 2020. Potensi pigmen fikobiliprotein sebagai agen antioksidan dan toksisitas hayati dari sianobakteria Chroococcus turgidus. Biopropal Industri. 11(1): 41.

Isailovic D, Li HW, Yeung ES. 2004. Isolation and characterization of R-phycoerythrin subunits and enzymatic digests. Journal of Chromatography A. 1051(1-2): 119-130.

Kawsar S, Yuki F, Ryo M, Hidetaro Y, Yasuhiro O. 2011. Protein R-phycoerythrin from marine red alga Amphiroa anceps: extraction, purification and characterization. Phytologia balcanica. 17(3): 347-354.

Kentish S, Ashokkumar M. 2011. The physical and chemical effects of ultrasound. Di dalam: Feng, Hao, Barbosa-Canovas, Gustavo V, Weiss, Jochen, editor. Ultrasound Technologies for Food and Bioprocessing. New York (US): Springer.

Kursar TA, Meer JVD, Alberte RS. 1983. Light harvesting system of the red alga Gracilaria tikvahiae. Plant Physiology. 73(2): 353-360.

Lemmli UK. 1970. Cleavage of structural proteins during the assembly of the head of Bacteriophage T4. Nature. 227(5259): 680-685.

Lee RE. 2008. Phycology fourth edition. New York (US): Cambridge University Press.

Liu W, Yu Y, Yang R, Wan C, Xu B, Cao S. 2010. Optimization of total flavonoid compound extraction from Gynura medica leaf using response surface methodology and chemical composition analysis. International Journal of Molecular Sciences. 11(11):47504763.

Marinho-Soriano E, PC Fonseca, MAA Carneiro, WSC Moreira. 2006. Seasonal variation in the chemical composition of two tropical seaweeds. Bioresource Technology. 97: 2402-2406.

Marsac, NT. 2003. Cyanobacterial phycobilisomes. Journal of Structural Biology. 124(2-3): 311-334.

Maulani RK, Marlina A, Gunarto I. 2017. Karakteristik jaringan secara histologi dari strain rumput laut (Kappaphycus alvarezii) yang terinfeksi penyakit ice-ice. Torani: JFMarSci. 1(1):45-57.

Mayasari NR, Karseno, Setyawati R. 2018. Identifikasi pigmen fikobiliprotein pada Kappaphycus alvarezii dalam pelarut buffer fosfat dengan metode freeze thaw cycle. Jurnal Mitra Kesehatan. 1(2): 96104.

Munier M, Dumay J, Morançais M, Jaouen P, Fleurence J. 2013. Variation in the biochemical composition of the edible seaweed Grateloupia turuturu Yamada harvested from two sampling sites on the Brittany Coast (France): the influence of the storage method on extraction og the seaweed pigment R-phycoerythrin. Journal of Chemistry.

Murtoyo AB, Susanto MM, Khoeri. 2010. Rumput laut sebagai penghasil agar dan karaginan. Yayasan Rumput Laut Indonesia. (1):1-116.

Niu JF, Wang GC, Tseng CK. 2006. Method for large-scale isolation and purification of R-phycoerythrin from red alga Polysiphonia urceolata Grev. Protein Expression and Purification. 49(1): 23-31.

Nurhayati, Mappiratu, Musafira. 2018. Pembuatan konsentrat protein dari biji kelor (Moringa oleifera 1.) dan analisis profil asam amino. Jurnal riset kimia KOVALEN. 4(1): 24-32.

Pan Q, Chen M, Li J, Wu Y, Zhen C, Liang B. 2013. Antitumor function and mechanism of phycoerythrin from Porphyra haitanensis. Biological Research. 46(1): 87-95.

Renaud SM, Luong-Van JT. 2006. Seasonal variations in the chemical composition of tropical Australian marine macroalgae. Journal of Applied Phycology. 18(3):381387. 
Rossano R, Ungaro N, D’Ambrosio A, Liuzzi GM, Riccio P. 2003. Extracting and purifying R-phycoeryhtrin from Mediterranean red algae Corallina elongate Ellis \& Solander. Journal of Biotechnology. 101(3): 289-293.

Rowan KS. 1989. Photosynthetic Pigments of Algae. New York (US): Cambridge University Press.

Sangeetha P, Babu S, Rengasamy R. 2017. Antioxidant properties of $\mathrm{r}$-phycoerythrin from Kappaphycus alvarezii. Journal of Innovative Research and Solutions. 3(1): 47-56.

Sethilkumar N, Suresh V, Thangam R, Kurinjimalar C, Kavitha G, Murugan P, Kannan S, Rengasamy R. 2013. Isolation and characterization of macromolecular protein R-phycoerythrin from Portieria hornemannii. International Journal of Biological Macromolecules. 55: 150-160.

Sharmila Banu VM, Santhosh S, Hemalatha V, Venkatakrishnan V, Dhandapani R. 2017. Optimization study on extraction \& purification of phycoerythrin from red algae Kappaphycus Alvarezii. Asian Journal of Pharmaceutical and Clinical Research 10(2): 297-302.

Sharmila G, Muthukumaran C, Suriya E, Muppidathi KR, Kamatchi M, Kumar NM, Anbarasan T, Jeyanthi J. 2019. Ultrasound aided extraction of yellow pigment from Tecoma castanifolia floral petals: Optimization by response surface method and evaluation of the antioxidant activity. Industrial Crops and Products.130: 467-477

Shirsath SR, Sonawane SH, Gogate PR. 2012. Intensification of extraction of natural products using ultrasonic irradiations- $A$ Review of current status. Chemical Engineering and Processing: Process Intensification 53: 10-23.

Sindumarta H, Natalia D. 1999. Catatan Kuliah Biokimia 1: Struktur dan Katalir. Jurusan Kimia MIPA. Bandung: ITB.

Sudhakar MP, Saraswathi M, Nair BB. 2014. Extraction, purification and application study of R-phycoerythrin from Gracilaria corticata J. Agardh var. corticata. Indian
Journal of Natural Products and Resources. 5(4): 371-374

Syafar A, Aslianti, Asyik N. 2019. Pengaruh penambahan rumput laut Eucheuma cottonii terhadap kualitas sensorik dan proksimat puding. Journal of Fisheries Processing Technology. 2(2): 244-250.

Tandeau NM. 2003. Phycobiliprotein and phycobilisome: the early observations. Photosythesis Research. 76(1-3): 193-205.

Treybal RE.1981. Mass Transfer Operations 3th ed. New York (US): McGraw-Hill Inc

Uju, Dewi NPSUK, Santoso J, Setyaningsih I, Hardingtyas SD, Yopi. 2020. Extraction of phycoerythrin from Kappaphycus alvarezii seaweed using ultrasonication. IOP Conference Series: Earth and Environmental Science. 414(2020): 012028.

Wang CC, Chou YY, Sheu SR, Jang MJ, Chen TH. 2011. Application of ultrasound thermal process on extracting flavor and caffeine of coffee. Thermal Science. 15(suppl.1): 69-74.

Wang H, Shi L, Yang X, Hong R, Li L. 2018. Ultrasonic-assisted extraction of natural yellow pigment from Physalis pubescens L. and its antioxidant activities. Journal of Chemistry. 2018.

Widyasanti A, Novira N, Endah W. 2018. Karakteristik fisikokimia antosianin ekstrak kulit buah naga merah menggunakan metode UAE. Jurnal Ilmiah Rekayasa Pertanian dan Biosistem. 6(1): 27-38.

Wong KH, Cheung PC. 2000. Nutritional evaluation of some subtropical red and green seaweed: proximate composition, amino acid profiles and some physicochemical properties. Food Chemistry. 7(4): 475-482.

Xiren GK, Aminah A. 2017. Proximate composition and total amino acid composition of Kappaphycus alvarezii found in the waters of Langkawi and Sabah, Malaysia. International Food Research Journal. 24(3):1255-1260.

Zawawi D, Hatta MZM, Kassim ASM, Aripin AM. 2014. Analysis of the chemical compositions and fiber morphology of 
pineapple (Ananas comosus) leaves in Malaysia. Journal of Applied Sciences. 14(12): 1355-1358.

Zhong Y, Shobo A, Hancock MA, Multhaup G. 2019. Label-free distribution of anti-amyloid D-AIP in Drosophila melanogaster: prevention of $\mathrm{A} \beta 42$ induced toxicity without side effects in transgenic flies. Journal of Neurochemistry. 150(1): 74-87. 